\title{
STEM and the Humanities
}

\section{Joel D. Benson}

Northwest Missouri State University, Maryville, MO, USA

Email: jbenson@nwmissouri.edu

How to cite this paper: Benson, J.D. (2017) STEM and the Humanities. Open Access Library Journal, 4: e3476. https://doi.org/10.4236/oalib.1103476

Received: February 22, 2017

Accepted: April 30, 2017

Published: May 3, 2017

Copyright $\odot 2017$ by author and Open Access Library Inc.

This work is licensed under the Creative Commons Attribution International License (CC BY 4.0).

http://creativecommons.org/licenses/by/4.0/

\begin{abstract}
Students today are told from the time they are in grade school that only by studying STEM subjects can they hope to expect a successful and meaningful career. Many people today question the value of a Liberal Arts education as outdated and elitist, insisting that students who study the Liberal Arts do not develop the skills necessary for the modern work force. To be fair, many faculty members in STEM subjects have acknowledged the importance of a well-rounded education, but we in the Humanities have our own shortcomings in this discussion. Instead of expecting the STEM subjects to recognize the importance of the Liberal Arts, the Humanities needs to reclaim its historical foundation and end this division. STEM subjects are part of the Humanities.
\end{abstract}

\section{Subject Areas}

Education, History

\section{Keywords}

Stem, Humanities, Liberal Arts, History

According to at least one university undergraduate catalog, the study of the Humanities "should be the foundation upon which every person bases his or her professional career" [1]. Yet students are told from the time they are in grade school that only by studying STEM subjects can they hope to expect a successful and meaningful career. Many people today question the value of a Liberal Arts education as outdated and elitist, insisting that students who study the Liberal Arts do not develop the skills necessary for the modern work force. To be fair, many faculty members in STEM subjects have acknowledged the importance of a well-rounded education, but supporters of the Humanities have their own shortcomings in this discussion. Instead of expecting the STEM subjects to recognize the importance of the Liberal Arts, the Humanities needs to reclaim its 
historical foundation and end this division. STEM subjects are part of the $\mathrm{Hu}-$ manities [2].

In fact, recent concerns with the decline in Humanities education are nothing new. In 1908, the American literary critic Irving Babbitt insisted that the humanities studies, particularly the study of classical literature, had to be defended "against the encroachment of physical science, as they once needed to be against the encroachments of theology" [3]. In 1937, the Spenser Trask Lectures at Princeton University were devoted to the general question of the meaning of the Humanities. For his part, Ralph Barton Perry, philosopher and a student of William James, defined the Humanities as those studies conducive to human freedom [4]. From 1947 to 1949, the University of Kansas held a series of lectures concerning the Humanities in which all the contributors adamantly defended the study of history, literature, and philosophy in higher education. A 1949 "Symposium on the Humanities in American Society" held at the University of Wisconsin, lamented the decline of the Humanities in College curricula in order to make way for studies in the sciences [5].

In 1959, the British novelist and scientist, C. P. Snow, delivered a lecture at the Senate House in Cambridge, subsequently published as The Two Cultures and the Scientific Revolution. Snow insisted that the division of intellectual life in Western society into the separate realms of the sciences and the Humanities was a major hindrance to solving the world's problems. Admittedly Snow was criticizing the British educational system for over-emphasizing the Humanities over the sciences, and he called for Britain to emulate German and American schools which sought to prepare their students equally in both areas [6].

Finally, in 1964 the federal "Commission on the Humanities" insisted that the expansion and advancement of the humanistic studies was in the national interest and deserved governmental financial support. This commission determined that the study of the Humanities included the following areas: the English language, literature, philosophy, modern and classical foreign languages (in their literary and historical aspects as opposed to communication skills), history and the social sciences, the visual arts, music, the performing arts, and those aspects of science and mathematics which widen man's understanding of his environment [7].

In response to this report, federal legislation in 1965 established the National Endowment for the Humanities. This act also included a list of the subjects accepted to be humanistic; one somewhat different from that of the commission. The National Endowment for the Humanities was to oversee the study of language (both modern and classical), ethics, comparative religion, archaeology, philosophy, jurisprudence, history, linguistics, the arts, and those aspects of the social sciences which are deemed to be humanistic. Somewhere in the legislative process, mathematics and the sciences lost their humanity [8].

As technology has advanced during the ensuing half century, the separation of the Humanities from STEM subjects has become increasingly stark. Unfortunately, recent attempts to recognize the importance of a liberal education in 
partnership with STEM subjects maintain a separation of the Humanities and STEM subjects instead of reclaiming a historical legacy of unity. The foundations of contemporary STEM subjects are found in the Humanities. In the classical world of Greece and Rome, an essential education prepared the individual for participation in public life. Initially the Liberal Arts included only three subjects: grammar, rhetoric, and logic, collectively known as the Trivium. But even here the foundations of western science and mathematics were established. Rhetoric involved more than simply persuasive eloquence. Rhetoric demanded the establishment of an argument, backed by rational criteria, elements necessary for any scientific inquiry. Similarly, all mathematics and science is founded upon the elements of formal logic. As such, in medieval times, the Liberal Arts were extended to include four additional subjects: arithmetic, geometry, music, and astronomy, named the Quadrivium. Admittedly, the seven liberal arts were presented in order; the Trivium being considered foundational for the Quadrivium, which was considered preparatory for the study of theology and philosophy, but a Liberal Arts education has always sought to prepare well-rounded individuals with a breadth of knowledge in all aspects of life; literary, artistic, mathematical, and technological, with a mastery of communication and critical thinking skills.

This inclusive understanding of the Liberal Arts was acknowledged and celebrated in a "Report on the Course of Instruction" at Yale College in 1828.

This document begins with these words.

In laying the foundation of a thorough education, it is necessary that all the important mental faculties be brought into exercise. It is not sufficient that one or two be cultivated, while others are neglected. A costly edifice ought not to be left to rest upon a single pillar [9].

This, of course, is the argument for the importance of the Liberal Arts, but the report goes on to say that the object of instruction at Yale College was to form in their students a proper character, established by a proportional balance of inquiry into the different branches of literature and science. The student was to learn deductive reasoning from mathematics and the process of induction and critical thinking from the physical sciences. English, literature, logic, philosophy, rhetoric, oratory, writing, and oral communication existed in a symbiotic union with science and mathematics, following the words of Cicero, extolling a "knowledge of many things" [10].

The original 1964 report, by the Commission on the Humanities, simply states that "the humanities are the study of that which is most human". In today's world, science, technology, engineering, and mathematics cannot be divorced from everyday life. The report also insists that the interdependence of science and the Humanities needs to be better understood to expand the possibilities, experiences, ideals and achievements for all humankind [11].

In an article in the Chronicle of Higher Education, entitled "Why Stem should care about the Humanities," Kira Hamman, instructor of mathematics at Penn State Mont Alto, clearly presents the new plan for scientists and mathematicians to rescue the Humanities. In today's world, one in which educational pragmat- 
ists have argued that the Liberal Arts are outdated and a waste of time, one in which politicians never argue against the teaching of STEM subjects, Hamman's arguments are both necessary and appreciated. She provides three cogent reasons why individuals in STEM subjects should "stick their necks out" and stand up for the Humanities. One: being outside the disciplines under attack lends credibility to their support. Two: "We're not as different as they think," acknowledging the common goals of creativity and critical thinking in both the sciences and the Humanities. And three: the true purpose of an education is to prepare students to lead a fuller life as global citizens; that material wealth is not the primary criterion by which an education should be judged [12].

Clearly Kira Hamman is not alone in expressing these sentiments. She and others in the natural sciences openly acknowledge the importance of the $\mathrm{Hu}$ manities and understand that a university is a place where all knowledge is celebrated, not for its monetary utility, but for its role in expanding the pantheon of ideas. Nevertheless, the Humanities should not be looking to the STEM subjects to be rescued from obsolescence. Teachers of the Humanities must stand up and reclaim their historic legacy. The core aims of all education, from the classical world of Greece and Rome, through the medieval universities, to the modern era has always been to prepare students with a breadth of knowledge in an increasing range of subjects, and a mastery of communication and critical thinking skills. As Rens Bod argues in his book, A New History of the Humanities, the current opposition between the sciences and the Humanities derives from the failure to recognize the pattern-seeking that lies at the heart of all learning [13].

Mathematics, and science, and geometry have always been part of a Liberal Arts education. It is no less elitist to proclaim the importance of the Humanities over science and mathematics, than it is for STEM to pronounce the death of the Humanities. The historic spirit of "university," the coming together as one, does not seek to "rest on a single pillar," but to provide students with the skills to build not just a career, but a life of value to themselves and the global community.

\section{References}

[1] Northwest Missouri State University Undergraduate Catalog, 2016-2017 (2016). Maryville, Missouri, 129.

[2] Hamman, K. (2013) Why STEM Should Care about the Humanities. http://chronicle.com/blogs/conversation/2013/04/12/why-stem-should-care-about-t $\underline{\text { he-humanities/ }}$

[3] Babbitt, I. (1986) Literature and the American College. National Humanities Institute, Washington DC, 87.

[4] Greene, T.M., Ed. (1938) The Meaning of the Humanities. Princeton University Press, Princeton, 41.

[5] Agard, W.A., Ed. (1949) The Humanities for Our Time. University of Kansas Press, Lawrence, Kansas.

Harris, J., Ed. (1950) The Humanities: An Appraisal. The University of Wisconsin Press, Madison, $\mathrm{x}$-xi. 
[6] Snow, C.P. (1960) The Two Cultures and the Scientific Revolution. Cambridge University Press, Cambridge.

[7] (1964) Report on the Commission on the Humanities. The American Council of Learned Societies, New York, 1-21.

http://www.acls.org/uploadedFiles/Publications/NEH/1964_Commission_on_the_ Humanities.pdf

[8] Bennett, W.J. (1984) To Reclaim a Legacy: Text of Report on Humanities in Education. Chronicle of Higher Education, 29, 17.

[9] A Committee of the Corporation, and the Academical Faculty (1828) Reports on the Course of Instruction in Yale College. Hezekiah Howe, New Haven.

http://collegiateway.org/reading/yale-report-1828/.

[10] "Reports." See also Cicero, De Oratore, Book I.

[11] Report on the Commission on the Humanities.

[12] Hamman, Why STEM Should Care about the Humanities.

[13] Bod, R. (2014) A New History of the Humanities. Oxford University Press, Oxford.

Submit or recommend next manuscript to OALib Journal and we will provide best service for you:

- Publication frequency: Monthly

- 9 subject areas of science, technology and medicine

- Fair and rigorous peer-review system

- Fast publication process

- Article promotion in various social networking sites (LinkedIn, Facebook, Twitter, etc.)

- Maximum dissemination of your research work

Submit Your Paper Online: Click Here to Submit

Or Contact service@oalib.com 